\title{
A RTICLES
}

\section{Evolution and Pathophysiology of Chronic Systolic Heart Failure}

\begin{abstract}
Barry E. Bleske, Pharm.D., FCCP
Understanding of the pathophysiology of chronic systolic heart failure evolved from a purely mechanical model to one in which a cascade of neurohormones and biologically active molecules are thought to be critical in the development, maintenance, and progression of the disease. Two important neurohormonal systems are the sympathetic nervous and renin-angiotensin-aldosterone systems. Initially, increases in norepinephrine concentrations from the sympathetic nervous system and in angiotensin II and aldosterone are beneficial in the short term to maintain cardiac output after an insult to the myocardium. However, long-term exposure to these neurohormones causes alterations of myocytes and interstitial make-up of the heart. These alterations in myocardium lead to progression of heart failure and, eventually, death.
\end{abstract}

(Pharmacotherapy 2000;20(11 Pt 2):349S-358S)

\section{OUTLINE}

Evolution in Pathophysiologic Models

Sympathetic N ervous System

RAA System

Angiotensin II

Aldosterone

Conclusion

An aging population and increased survival after myocardial infarction contribute to the prominent role of chronic heart failure in today's society. According to recent statistics, nearly 5 million persons in the United States have heart failure, with 400,000 new cases diagnosed every year. ${ }^{1}$ It is estimated that the syndrome accounts for over 900,000 hospitalizations/year and is the most common diagnosis in hospital patients aged 65 years and older. ${ }^{1}$ Significant mortality is associated with the disease. After a diagnosis, 5year mortality is 50\%; however, in any given patient, 1-year mortality may range from 5-50\% depending on disease severity. The cost to treat

From the University of Michigan College of Pharmacy and University of Michigan Health Systems, Ann Arbor, Michigan.

Address reprint requests to Barry E. Bleske, Pharm.D., University of Michigan, College of Pharmacy, 428 Church Street, Ann Arbor, MI 48109-1065. heart failure is also staggering, estimated to be \$17.8-56 billion annually, which does not take into account associated costs endured by caregivers. ${ }^{1,2}$ Since heart failure is so prevalent and devastating, vast amounts of time and energy have been devoted to understanding its pathophysiology. Much work has focused on the role of the sympathetic nervous and reninangiotensin-aldosterone (RAA) systems.

\section{Evolution in Pathophysiologic Models}

Understanding of the pathophysiology of heart failure evolved over the years as investigators pieced together the complex interplay of mechanical, biologic (endocrine, paracrine, autocrine), and functional alterations that occur. As our understanding increased, so did the complexity of the model to define the disease. Thirty to 40 years ago heart failure was looked at as a syndrome of salt and water retention that was due in part to abnormalities of renal blood flow. This cardiorenal model evolved into a cardiocirculatory model when hemodynamic measurements revealed a decrease in cardiac output and increase in peripheral vascular resistance. 3 Based on these models, diuretics were administered to treat sodium and water 
retention, and vasodilators and inotropic agents were administered to improve hemodynamics by increasing cardiac output and decreasing peripheral vascular resistance.

Although these models explain clinical manifestations and rationalize drug therapy, they do not adequately describe the devastating progression that occurs in treated patients with either asymptomatic or symptomatic heart failure. In attempt to describe disease progression in addition to renal and circulatory change, the neurohormonal model was put forward in the 1980s (Figure 1). 5-7 Heart failure begins with an insult or damage to the heart that results in a sustained decrease in cardiac function and output. This insult varies and may include coronary artery disease (ischemic dilated cardiomyopathy, which affects approximately two-thirds of patients), hypertension, and idiopathic causes (idiopathic dilated cardiomyopathy). A small number of patients may have other causes, such as ethanol abuse, druginduced cardiomyopathy (doxorubicin), and viral infections.

After the insult and a sustained decrease in cardiac output, excessive neurohormonal activation occurs, specifically with the sympathetic and RAA systems, that causes sodium and water retention together with peripheral vasoconstriction. Initially, these neurohormones are compensatory and may maintain relatively normal cardiac output in the short term. However, long-term elevated concentrations of neurohormones result in toxicity, overcompensation, and eventually inability to maintain a normal cardiac function. With a sustained decrease in cardiac function, further neurohormonal activation, sodium and water retention, and peripheral vasoconstriction occur. A vicious cycle is created that leads to more symptoms, disease progression, and, eventually, death.

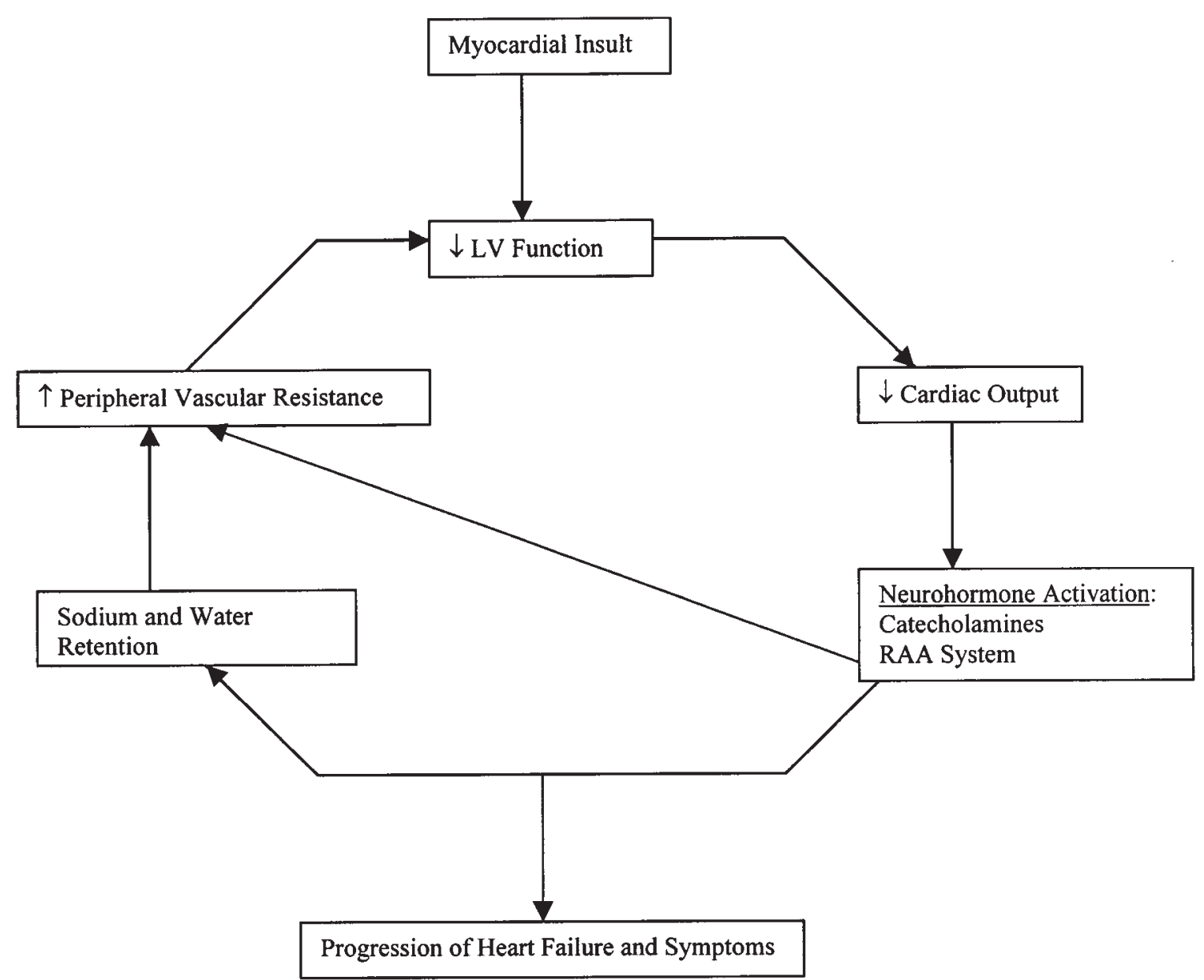

Figure 1. Pathophysiology of heart failure in the 1980s. 
The neurohormonal model is still in vogue and is similar to what was proposed, but it now includes other neurohormones or biologically active molecules. The model appears to be applicable based on the following: experimental studies showed the ability of neurohormones to contribute to the development and progression of heart failure either in an intact or cellular model; clinical studies proved the benefit of neurohormonal antagonists; and regardless of the cause or type of heart failure, neurohormonal activation appeared to be similar. ${ }^{3,8-16}$ In addition to the contribution of biologically activated molecules such as endothelin, vasopressin, tumor necrosis factor- $\alpha$, and counterregulatory neurohormones (atrial and brain natriuretic peptide), the model describes the role of left ventricular remodeling in disease progression. ${ }^{10,17-19}$

Left ventricular remodeling occurs due to alterations in hemodynamics (increase preload) and load-independent changes in myocyte biology and chamber geometry (Figure 2). At

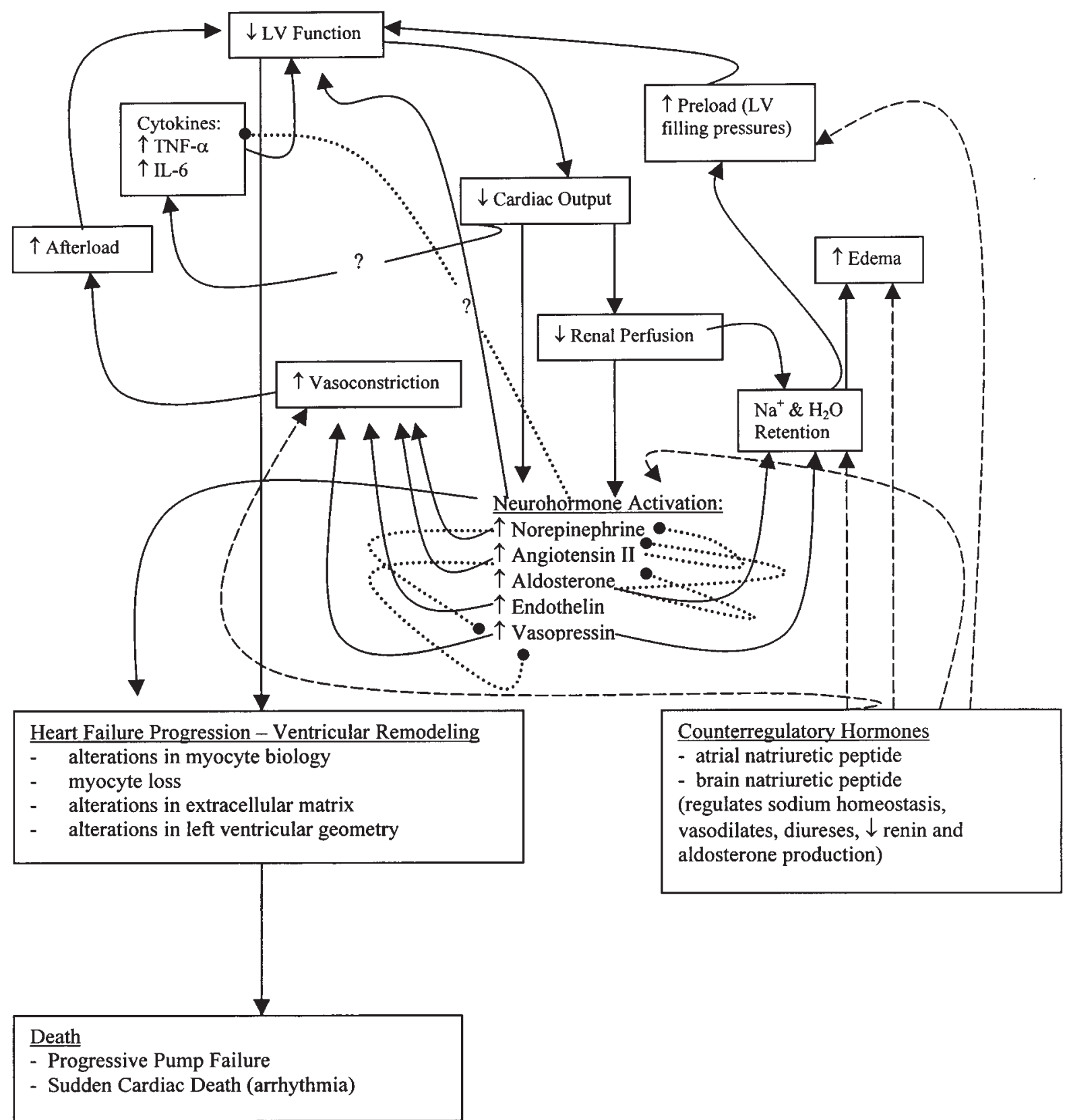

Figure 2. Pathophysiology of chronic systolic heart failure today. Direct effect $=-->$; counterregulatory effect $=--->$; induce production or increase effect of a biologically active molecule $=\ldots \ldots \ldots . . . \cdot$. 
first it occurs to maintain stroke volume and contractility by enlarging the ventricle and increasing myocardial and interstitial mass. At the cellular level, remodeling may occur by several mechanisms, including myocyte hypertrophy, interstitial growth, and myocyte slippage. Over time these changes become maladaptive, leading to increased wall stress and oxygen demand, together with fibrosis and decreased contractility. Further discussion relating to cellular and molecular changes that occur during heart failure is available el sewhere. ${ }^{3,20,21}$

The current model, as can be expected, is not complete and continues to evolve. Critical pieces of information, such as specific roles and interplay among biologically active molecules, genetic determinations, and how the transition from asymptomatic to symptomatic heart failure occurs, are missing. Fortunately, however, the sympathetic nervous and RAA systems have clarified many important aspects of the pathophysiology of the syndrome.

\section{Sympathetic Nervous System}

The significance of the sympathetic nervous system, specifically norepinephrine, in heart failure probably has been known for at least 25 years. Classic data from the 1980s showing that norepinephrine concentrations were el evated and were a prognostic indicator for mortality further focused research efforts on the system. ${ }^{22}, 23$ This led to therapy with $\beta$-adrenergic receptor antagonists, which once were thought to be harmful in the treatment of heart failure.

Initially, an increase in norepinephrine concentrations may have beneficial short-term effects by increasing heart rate, contractility, and blood pressure, which maintain normal cardiac output after an insult to the myocardium. However, long-term effects have direct adverse effects on the heart that are mediated by excess activation of the cardiac adrenergic receptor pathway. ${ }^{24-29}$ In support of these data, transgenic animal models in which $\beta$ - and $\alpha$-adrenergic receptors are overexpressed developed cardiomyopathies and cardiac hypertrophy. In these models, the $\beta_{1}$-receptor may be the most important in causing overt heart failure. ${ }^{29,30}$

Activation of the sympathetic adrenergic system occurs early in the syndrome, beginning with cardiac followed by systemic adrenergic activation. $^{31,32}$ Sustained adrenergic activation results in alterations in the cardiac adrenergic receptor profile and in desensitization of signal transduction through $\beta$-adrenergic receptors, which results in decreases in myocardial reserve and exercise capacity. In a nonfailing heart the $\beta_{1-:}: \beta_{2}$-receptor ratio is approximately $80: 20$. In the failing heart, downregulation of the $\beta_{1}$ receptor alters the ratio to approximately $60: 40,33,34$ In addition to changes in the $\beta$-adrenergic pathway, upregulation of $\alpha_{1}$-receptors causes a further change in the overall cardiac adrenergic receptor profile. ${ }^{35,36}$

Desensitization or reduction of $\beta$-receptor signal transduction due to excess activation by norepinephrine may occur through several mechanisms. One is downregulation of $\beta_{1^{-}}$ receptors; another is uncoupling of the $\beta$ receptor from its effector site, adenylyl cyclase. ${ }^{37-39}$ Both $\beta_{1}$ - and $\beta_{2}$-receptors are coupled to adenylyl cyclase through the stimulatory $\mathrm{G}$ protein. Adenylyl cyclase converts adenosine triphosphate to cyclic adenosine monophosphate (CAMP), which acts on protein kinase $A$, which leads to phosphorylation of cellular proteins, resulting in an increase in intracellular calcium from, in part, sarcoplasmic reticulum. The increase in intracellular calcium causes myocardial inotropic and chronotropic response. Therefore, uncoupling of the $\beta$ receptor to adenylyl cyclase leads to myocardial dysfunction. Uncoupling of the $\beta_{2}$-adrenergic receptor occurs in ischemic and idiopathic dilated cardiomyopathy, and uncoupling of $\beta_{1^{-}}$ adrenergic receptor in ischemic dilated cardiomyopathy. 24,37

Another mechanism for abnormal signal transduction is upregulation of $\beta$-adrenergic receptor kinase ( $\beta A R K-1) .{ }^{40-43}$ Increased $\beta A R K$ 1 activity leads to receptor phosphorylation and may contribute to receptor uncoupling. An increase in $\mathrm{G}$-inhibitory $\left(G_{i}\right)$ protein activity causes signal transduction abnormalities, probably through receptor uncoupling. ${ }^{44-47}$ These and other mechanisms may account for 50-60\% loss in total signal transducing potential, resulting in decreased myocardial function. ${ }^{24}$

In addition to desensitization of signal transduction, sustained adrenergic activation has a direct adverse biologic effect on cardiac myocytes that contributes to myocardial dysfunction. Alteration in myocyte function, specifically cell loss, may occur by either necrosis or apoptosis. ${ }^{9,}$ 48-52 Data from cultured cardiac myocytes indicate that at norepinephrine concentrations seen clinically, necrosis occurs. ${ }^{48}$ In addition to a direct effect, ischemia due to increase oxygen demand and a decrease in 
oxygen delivery may contribute to cell necrosis. Apoptosis appears to be mediated mainly through the $\beta_{1}$-receptor. ${ }^{53,54}$ Recent data suggest that stimulation of the $\beta_{2}$-receptor and activation of $G_{i}$ proteins and mitogen-activated protein kinase actually may have antiapoptotic effects. $^{54-56}$ A decrease in myocyte function due to alteration in gene expression also may occur. This includes alterations in calcium handling by the myocyte, such as decreased expression of sarcoplasmic reticulum $\mathrm{Ca}^{2+}$-adenosine triphosphatase, a protein that is necessary for excitationcontraction coupling. ${ }^{57}$ Other effects may include fetal gene expression, activation of fibroblast growth factor, myocyte hypertrophy, and changes in the proteins responsible for $\beta$ adrenergic signal transduction. ${ }^{58-62}$ These factors are also important in contributing to left ventricular remodeling that occurs in patients with systolic failure.

Overall, alteration in both signal transduction and the biology of myocytes due to activation of the sympathetic nervous system contributes to the myocardial dysfunction that is observed in patients with chronic systolic heart failure and leads to symptoms and progression of heart failure.

\section{RAA System}

The RAA system is activated in patients with heart failure. Similar to the sympathetic nervous system, initial activation may be important to maintain cardiac output in a damaged heart by increasing preload through sodium retention and volume expansion. Perfusion also may be maintained by vasoconstriction. However, longterm effects of prolonged activation of the RAA system are deleterious through excessive hemodynamic alterations and direct effects on myocardium. These effects are mediated in part by production and formation of renin, angiotensin II (ATII), and aldosterone. Renin, which is produced in the juxtaglomerular cells of the kidneys, is increased by three main factors: decreased blood flow to the kidneys, decreased serum sodium, and increased sympathetic tone. ${ }^{63}$ Renin then converts circulating angiotensinogen to angiotensin I (ATI), which is inactive. Angiotensin I is converted to ATII by either angiotensin-converting enzyme (ACE) or a nonACE pathway (Figure 3). In this so-called alternative or independent pathway, chymase and cathepsin G may convert ATI to ATII; other molecules such as elastase, tonin, and tissue plasminogen activator may directly convert angiotensinogen to ATII. ${ }^{64-71}$ This alternative pathway may account for significant production ( $>50 \%$ ) of ATII. ${ }^{72,73}$ The ACE also effects the kallikrein-kinin system by inactivating bradykinin, a potentially important vasodilatory activator. N eutral endopeptidase also inactivates bradykinin and natriuretic peptides. In addition to circulating angiotensinogen and $A C E$, both molecules may be produced by a variety of tissues, resulting in local production of ATII, which may have important autocrine and paracrine actions that may contribute significantly to the pathophysiology of heart failure. ${ }^{74-77}$

\section{Angiotensin II}

Effects of ATII are mediated by the activation of specific angiotensin receptors, $\mathrm{AT}_{1}$ and $A \mathrm{~T}_{2}{ }^{78 \text {, }}$ 79 Both receptors have high affinity for ATII but are functionally distinct. They are located throughout the body including the kidneys, brain, endothelium, and heart. ${ }^{80-83}$ Binding of $A T I I$ to $A T_{1}$ and $A T_{2}$ receptors may produce biologic effects that may be important to the pathophysiology of heart failure. The AT 1 receptor-signaling pathway interacts with both adenylate cyclase and the $G$ protein system. Stimulation of the $A T_{1}$ receptor causes activation of several phospholipases, leading to an increase in inositol 1,4,5 triphosphate, which stimulates intracellular calcium release and vasoconstriction. ${ }^{84-88}$ In addition, $\mathrm{AT}_{1}$ stimulation leads to a decrease in CAMP by $G_{i}$, which may contribute to vasoconstriction observed with ATII. ${ }^{83,87}$ Activation of the $A T_{1}$ receptor causes an increase in the L-type calcium channel opening, resulting in an increase in intracellular calcium that may be a stimulus for aldosterone production in adrenal cells. ${ }^{87,89}$ Through this receptor, ATII also activates Janus kinases (JAK), signal transducers, and activators of transcription, which may cause activation of early growthresponse genes, resulting in proliferative effects (myocardial hypertrophy). ${ }^{90-93}$ In addition, the $\mathrm{AT}_{1}$ pathway may activate a number of protooncogens that ultimately regulate genes involved with cell growth and extracellular matrix proteins. ${ }^{87,94-97}$ This process is important for myocardial hypertrophy and alteration in the collagen make-up of the heart.

Overall, the consequences of $\mathrm{AT}_{1}$ activation by ATII is significant with regard to the pathophysiology of heart failure. They include vasoconstriction of blood vessels, release of 
aldosterone and catecholamines from adrenal glands, release of vasopressin from the pituitary (leading to sodium and water retention), catecholamine release from the presynaptic terminal, myocardial hypertrophy, and alteration in the extracellular matrix of the heart. These effects may lead to symptoms and, most significant, progression of heart failure.

The role of the $\mathrm{AT}_{2}$ receptor is less well known but appears to modulate or have the opposite effects of the $A T_{1}$ receptor. Angiotensin II stimulation of the $\mathrm{AT}_{2}$ receptor may result in vasodilation by increasing nitric oxide. ${ }^{98}$ Activation of the receptor may lead to antiproliferative effects and may cause apoptosis. ${ }^{99-103}$ Theoretically, this may be beneficial in heart failure by counteracting negative effects that occur by ATII activation of the AT 1 receptor.

\section{Aldosterone}

Aldosterone may play a significant role in the pathophysiology of heart failure that goes beyond sodium and water retention. Circulating or plasma concentrations of aldosterone are produced in the adrenals. Angiotensin II stimulation of the $A T_{1}$ receptor increases aldosterone secretion, although other mechanisms also may do this, such as plasma potassium, adrenocorticotropic hormone, and endothelin, and decreased metabolic clearance. ${ }^{104-108}$ These mechanisms may become important when ATII concentrations are suppressed by drug therapy with ACE inhibitors. This may account in part for the observation that aldosterone levels are suppressed only transiently but not over the long term after ACE inhibitor therapy. ${ }^{109-111}$ This finding is referred to as aldosterone escape. Local

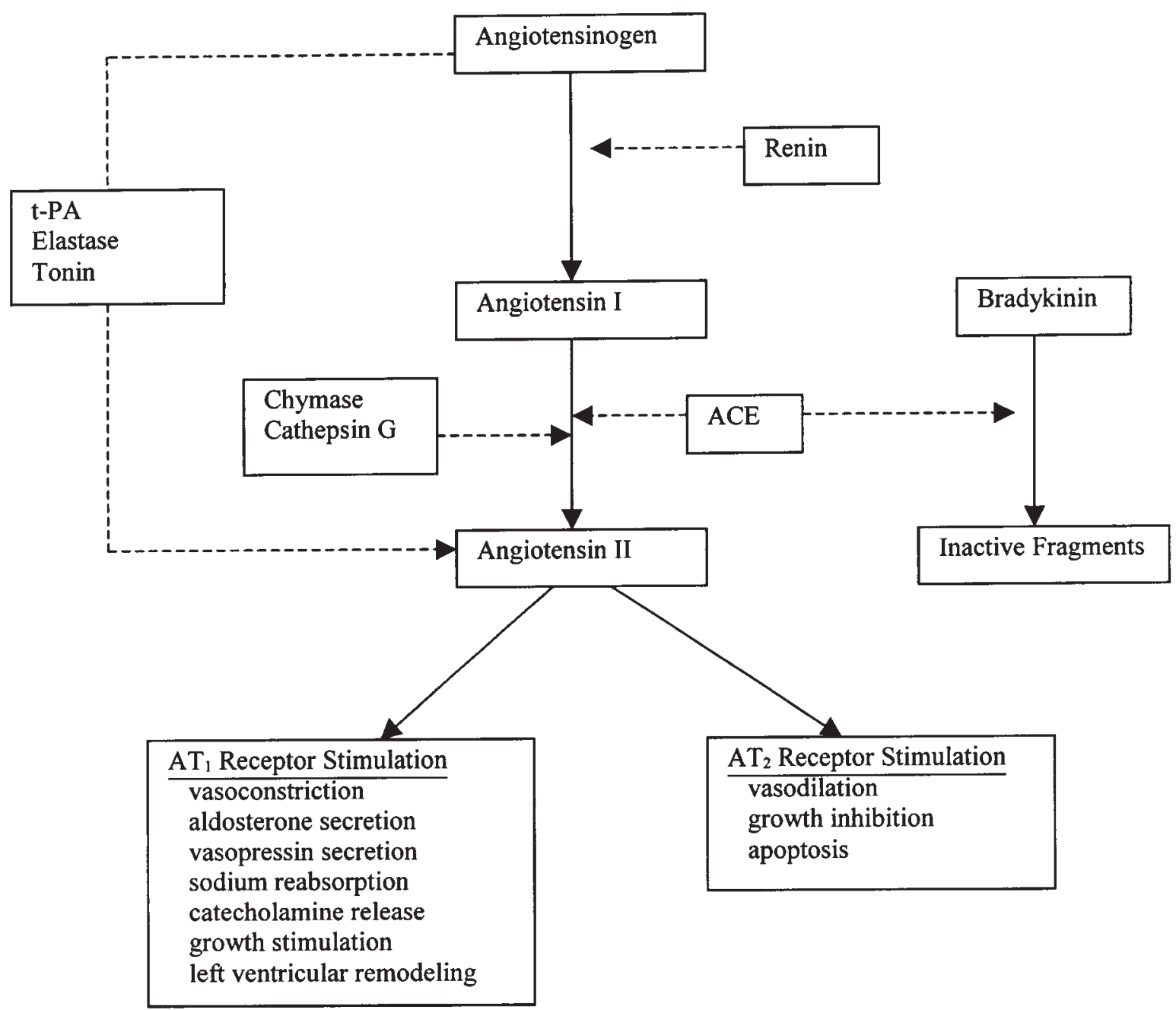

Figure 3. The renin-angiotensin-aldosterone system. ACE = angiotensin-converting enzyme. 
synthesis of aldosterone may have important autocrine and paracrine effects on cardiovascular tissue because concentrations may be higher there than circulating aldosterone concentrations. ${ }^{112-114}$

Increased aldosterone concentrations may contribute significantly to the pathophysiology of heart failure and appear to be a prognostic indicator. Post hoc analysis from the Cooperative North Scandinavian Enalapril Survival Study (CONSENSUS) showed that plasma levels elevated at baseline were associated with increased mortality $(p<0.01)$ in patients with symptomatic New York Heart Association class IV disease. ${ }^{115}$

For several reasons, aldosterone may be important in the prognosis and pathophysiology of heart failure. It can promote sodium and water retention while increasing magnesium and potassium excretion. ${ }^{116}$ Sodium and water retention can contribute to the symptoms of heart failure, and electrolyte loss may promote arrhythmia formation. Aldosterone also prevents uptake of norepinephrine by myocardium, which may be arrhythmogenic especially in the setting of low magnesium and potassium levels. ${ }^{110,116}$ It may reduce parasympathetic activity in part by directly decreasing baroreceptor discharge from the carotid sinus. ${ }^{117-119}$ Reduced parasympathetic activity may be associated with increased mortality. ${ }^{120,121}$ Another mechanism by which aldosterone may contribute to the pathophysiology of heart failure is to stimulate collagen production, resulting in myocardial fibrosis that may contribute to left ventricular remodeling and dysfunction. ${ }^{122-124}$ Aldosterone may cause vascular damage and decrease blood vessel compliance that may contribute to ischemia, which may promote arrhythmia formation and potentially heart failure progression. ${ }^{125,126}$ Animal data suggest that it may increase ATII binding and increase ATII hypertrophic response. ${ }^{127}$ Overall, similar to ATII, and by several mechanisms, aldosterone significantly alters hemodynamics and has a direct effect on myocardium.

\section{Conclusion}

The pathophysiology of heart failure is complex and cannot be defined in simple terms. Based on information from animal and human studies, both the sympathetic nervous and RAA systems at many different levels contribute significantly to disease maintenance and progression. Therapies targeted at the pathophysiology of heart failure, or more specifically at these neurohormonal systems, are effective. They may not only significantly decrease morbidity and mortality but attenuate and, on some levels, actually reverse disease progression. As our understanding of heart failure continues to evolve, the approach to treatment will lead to new therapies including other neurohormonal antagonists and perhaps even gene therapy specifically design to arrest and reverse this devastating syndrome.

\section{References}

1. American Heart Association. 2000 heart and stroke statistical update. Available from: http://americanheart.org.

2. O'C onnell JB. The economic burden of heart failure. Clin Cardiol 2000;23(suppl III):6-10.

3. Mann DL. Mechanisms and models in heart failure. A combinatorial approach. Circulation 1999;100:999-1008.

4. Packer M. How should physicians view heart failure? The philosophical and physiological evolution of three conceptual models of the disease. Am J Cardiol 1993;71:C3-11.

5. Packer $\mathbf{M}$. The neurohormonal hypothesis: a theory to explain the mechanism of disease progression in heart failure. J Am Coll Cardiol 1992;20:248-54.

6. Bristow MR. The adrenergic nervous system in heart failure. N Engl J Med 1984;311:850-1.

7. MCC all D, O'Rourke RA. Congestive heart failure. I. Biochemistry, pathophysiology and neuro-humoral mechanisms. Mod Concepts Cardiovasc Dis 1985;54:55-9.

8. Tan LB, Jalil JE, Pick R, Janicki JS, Weber KT. Cardiac myocyte necrosis induced by angiotensin II. Circ Res 1991;69:1185-95.

9. Mann DL, Kent RL, Parsons B, Cooper G IV. Adrenergic effects on the biology of the adult mammalian cardiocyte. Circulation 1992;84:790-804.

10. Bozkurt B, Kribbs S, Clubb FJ Jr, et al. Pathophysiologically relevant concentrations of tumor necrosis factor- $\alpha$ promote progressive left ventricular dysfunction and remodeling in rats. Circulation 1998;97:1382-91.

11. Cohn JN, Johnson G, Ziesche S, et al. A comparison of enalapril with hydralazine-isosorbide dinitrate in the treatment of chronic congestive heart failure. N Engl J Med 1991;325:303-10.

12. The SOLVD Investigators. Effect of enalapril on survival in patients with reduced left ventricular ejection fractions and congestive heart failure. N Engl J Med 1991;325:293-302.

13. The SOLVD Investigators. Effect of enalapril on mortality and the development of heart failure in asymptomatic patients with reduced left ventricular ejection fractions. N Engl J Med 1992:327:685-91.

14. Paker M, Bristow MR, C ohn JN, et al. The effect of carvedilol on morbidity and mortality in patients with chronic heart failure. N Engl J Med 1996;334:1350-5.

15. MERIT-HF Study Group. Effect of metoprolol $C R / X L$ in chronic heart failure: metoprolol CR/XL randomized intervention trial in congestive heart failure (MERIT-HF). Lancet 1999;353:2001-7.

16. CIBIS-II Investigators and Committees. The cardiac insufficiency bisoprolol study II (CIBIS-II): a randomized trial. Lancet 1999;353:9-13.

17. Deedwania PC. Endothelin, the bad actor in the play: a marker or mediator of cardiovascular disease. J Am Coll Cardiol 1999;33:939-42.

18. Goldsmith SR. Vasopressin: a therapeutic target in congestive heart failure? J Cardiac Failure 1999;5:347-56.

19. Levin ER, Gardner DG, Samson WK. Natriuretic peptide. N 
Engl J Med 1998;339:321-8.

20. Colucci WS. Molecular and cellular mechanisms of myocardial failure. Am J Cardiol 1997;80(11A):15L-25.

21. Kurrelmeyer K, Karla D, Bozkurt B, et al. Cardiac remodeling as a consequence and cause of progressive heart failure. Clin Cardiol 1998:21(suppl I):14I-19.

22. Cohn JN, Levine TB, Olivari MT, et al. Plasma norepinephrine as a guide to prognosis in patients with chronic congestive heart failure. $N$ Engl J Med 1984;311:819-23.

23. Leimbach W N Jr, Wallin GB, Victor RG, Aylward PE, Sundlof G, Mark AL. Direct evidence from intraneural recordings for increased sympathetic outflow in patients with heart failure. Circulation 1986;73:913-19.

24. Bristow MR. Mechanism of action of beta-blocking agents in heart failure. Am J Cardiol 1997;80:26L-40.

25. Port JD, Wienberger HD, Bisognano JD, et al Echocardiographic and histopathological characterization of young and old transgenic mice over-expressing the human $\beta$ adrenergic receptor [abstr]. J Am Coll Cardiol. 1998:31(suppl A):177A.

26. Engelhardt S, Hein L, Wiesman F, Lohse MJ. Progressive hypertrophy and heart failure in $\beta 1$-adrenergic receptor transgenic mice. Proc Natl Acad Sci USA 1999;96:7059-64.

27. Communal C, Singh K, Pimental DR, Colucci WS. Norepinephrine stimulates apoptosis in adult rat ventricular myocytes by activation of the $\beta$-adrenergic receptor. Circulation 1998;98:1329-34.

28. Milano CA, Dolber PC, Rockman HA, et al. Myocardial expression of a constitutively active $\alpha_{\mid \mathrm{B}}$-adrenergic receptor in transgenic mice induces cardiac hypertrophy. Proc. Natl Acad Sci USA 1994;91:10109-13.

29. Liggett SB, Tepe NM, Lorenz JN, et al. Early and delayed consequences of $\beta_{2}$-adrenergic receptor overexpression in mouse hearts. Circulation 2000;101:1707-14.

30. Lefkowitz RJ, Rockman HA, Koch WJ. Catecholamines, cardiac $\beta$-adrenergic receptors, and heart failure. Circulation 2000;101:1634-7.

31. Esler M, Kaye D, Lambert G, Esler D, Jennings G . Adrenergic nervous system in heart failure. Am J Cardiol 1997;80:7L-14.

32. Rundquist B, Elam M, Bermann-Sverrisdottir Y, Eisenhofer G, Friberg P. Increased cardiac adrenergic drive precedes generalized sympathetic activation in human heart failure. Circulation 1997:95:169-75.

33. Bristow $\mathbf{M R}$, Ginsburg $\mathbf{R}$, Fowler $\mathbf{M}$, et al. $\beta_{1^{-}}$and $\beta_{2^{-}}$ adrenergic receptor subpopulations in normal and failing human ventricular myocardium: coupling of both receptor subtypes to muscle contractions and selective $\beta_{1}$-receptor downregulation in heart failure. Circ Res 1986;59:297-309.

34. Brodde OE, Schuler S, Kretsch R, et al. Regional distribution of $\beta$-adrenoceptors in the human heart: coexistence of functional $\beta_{1}$ - and $\beta_{2}$-adrenoceptors in both atria and ventricles in severe congestive cardiomyopathy. J Cardiovasc Pharmacol 1986;8:1235-42.

35. Bristow MR. Changes in myocardial and vascular receptors in heart failure. J Am Coll Cardiol 1993;22(suppl A):61A-71.

36. Bristow MR. $\beta$-Adrenergic receptor blockade in chronic heart failure. Circulation 2000;101:558-69.

37. Bristow MR, Anderson FL, Port JD, et al. Differences in $\beta$ adrenergic neuroeffector mechanisms in ischemic vs. idiopathic dilated cardiomyopathy. Circulation 1991;84: 1024-39.

38. Bristow $\mathbf{M R}$, Minobe $\mathbf{W}$, Rasmussen $\mathbf{R}$, et al. $\beta$-Adrenergic neuroeffector abnormalities in the failing human heart are produced by local, rather than systemic mechanisms. J Clin Invest 1992;89:803-15.

39. Bristow MR, Hershberger RE, Port JD, Rasmussen R. $\beta_{1}$ and $\beta_{2}$ adrenergic receptor mediated adenylate cyclase stimulation in nonfailing and failing human ventricular myocardium. $\mathrm{Mol}$ Pharmacol 1989;35:295-303.

40. Koch WJ, Rockman HA, Samama $P$, et al. Cardiac function in mice overexpressing the $\beta$-adrenergic receptor kinase or a
BARK inhibitor. Science 1995;268:1350-3.

41. Ungerer $\mathbf{M}$, Parruti $\mathbf{G}$, Bohm $\mathbf{M}$, et al. Expression of $\beta$ arrestins and $\beta$-adrenergic receptor kinases in the failing human heart. Circ Res 1994;74:206-13.

42. Freedman NJ, Liggett SB, Drachman DE, et al. Phosphorylation and desensitization of the human $\beta_{1-}$ adrenergic receptor. J Biol Chem 1995;270:17953-61.

43. Roth NS, Campbell PT, Caron MG, et al. Comparative rates of desensitization of $\beta$-adrenergic receptors by the $\beta$ adrenergic receptor kinase and the cyclic AMP-dependent protein kinase. Proc Natl Acad Sci USA 1991;88:6201-4.

44. Feldman AM, Gates AE, Veazey W B, et al. Increase of the $M_{r}$ 40,000 pertussis toxin substrate ( $G$ protein) in the failing human heart. J Clin Invest 1988;82:189-97.

45. Feldman AM, Jackson DG, Bristow MR, Cates AE, Van Dop C. Immunodetectable levels of the inhibitory guanine nucleotide binding proteins in failing human heart: discordance with measurements of adenylate cyclase activity and levels of pertussis toxin substrate. J Mol Cell Cardiol 1991;23:439-52.

46. Neumann J, Schmitz W, Scholz H, Myernick LV, Doring V, Kalma $\mathbf{P}$. Increase in myocardial $G_{i}$ proteins in heart failure. Lancet 1988:2:936-7.

47. Bohm M, Eschenhagen $\mathbf{T}$, Gierschik $\mathbf{P}$, et al. Radioimmunochemical quantifications of Gla in right and left ventricles from patients with ischemic and dilated cardiomyopathy and predominant left ventricular failure. J Mol Cell Cardiol 1994;26:133-49.

48. Haft JI. Cardiovascular injury induced by sympathetic catecholamines. Prog Cardiovasc Dis 1974;17:73-85.

49. Sabbah HN. The cellular and physiological effects of beta blockers in heart failure. Clin Cardiol 1999;22(suppl V): $\mathrm{V} 16-20$

50. Searle J, Kerr JF, Bishop CJ. Necrosis and apoptosis: distinct modes of cell death with fundamentally different significance. Pathol Annu 1982;17:229-59.

51. Narula J, Haider N, Virmani R, et al. Apoptosis in myocytes in end-stage heart failure. N Engl J Med 1996;335:1182-9.

52. Geng YJ, Ichikawa Y, Vatner DE, et al. Overexpression of Gs $\alpha$ accelerates programmed death (apoptosis) of myocardiocytes in transgenic mice [abstr]. Circulation Suppl 1996;94:1640

53. Communal C, Singh K, Sawyer DE, et al. Opposing effects of $\beta_{1}$-and $\beta_{2}$-adrenergic receptors on cardiac apoptosis: role of a pertussis toxin-sensitive G protein. Circulation 1999;100: 2210-12.

54. Zaugg M, Xu W, Lucchinetti E, Shafiq SA, Jamali NZ, Siddiqui MAQ. $\beta$-Adrenergic receptor subtypes differentially affect apoptosis in adult rat ventricular myocytes. Circulation 2000;102:344-50

55. Daaka Y, Luttrell LM, Lefkowitz RJ. Switching of the coupling of the $\beta_{2}$-adrenergic receptor to different $G$ proteins by protein kinase A. Nature 1997;390:88-91.

56. Sheng Z, Knowlton K, Chen J, et al. Cardiotrophin 1 (CT-1) inhibition of cardiac myocyte apoptosis via a mitogenactivated protein kinase-dependent pathway. J Biol Chem 1997;272:5783-91.

57. Arai M, Alpert NR, MacLennan DH, Barton P, Periasamy M. Alterations in sarcoplasmic reticulum gene expression in human heart failure. Circ Res 1993;72:463-9.

58. Takahashi N, Calderone A, Izzo NJ Jr, Maki TM, Marsh JD, Colucci WS. Hypertrophic stimuli-induced transforming growth factor- $\beta_{1}$ expression in rat ventricular myocytes. J Clin Invest 1994;94:1470-83.

59. Parker TG, Parker SE, Schneider MD. Peptide growth factors can provoke "fetal" contractile protein gene expression in rat cardiac myocytes. J Clin Invest 1990;85:507-14.

60. Calderone A, Takahashi N, Izzo NJ, Thaik CN, Colucci WS. Pressure- and volume -induced left ventricular hypertrophies are associated with distinct myocyte phenotypes and differential induction of peptide growth factor mRNAs. Circulation 1995;92:2385-90

61. Schwartz K, Boheler KR, DeLaBastie D, Lompre A-M, Mercadier JJ. Switches in cardiac muscle gene expression as a 
result of pressure and volume overload. Am J Physiol 1992;262:R364-9.

62. Lowes BD, Minobe W, Abraham WT, et al. Changes in gene expression in the intact human heart: downregulation of alpha-myosin heavy chain in hypertrophied, failing ventricular myocardium. J Clin Invest 1997;100:2315-24.

63. Peach MJ. Renin-angiotensin system: biochemistry and mechanisms of action. Physiol Rev 1977;57(2):313-70.

64. Dzau VJ. Multiple pathways of angiotensin production in the blood vessel wall: evidence, possibilities and hypotheses. J Hypertens 1989;7:933-6.

65. Urata H, Kinoshita A, Misono KS, Bumpus FM, Husain A. Identification of a highly specific chymase as the major angiotensin II-forming enzyme in human heart. J Biol Chem 1990;265:22348-57.

66. Dzau VJ, Gonzalez D, Kaempfer C, Dubin D, Wintroub BU. Human neutrophils release serine proteases capable of activating prorenin. Circ Res 1987;60:595-601.

67. Wintroub BU, Klickstein LB, Watt KW. A human neutrophil dependent pathway for generation of ang II. J Clin Invest 1981;68:484-90.

68. Dzau VJ, Sasamura H, Hein L. Heterogeneity of angiotensin synthetic pathways and receptor subtypes; physiological and pharmacological implications. J Hypertens 1993;11:S13-18.

69. Boucher R, Asselin JH, Genest J. A new enzyme leading to direct formation of angiotensin II. Circ Res 1994;34(suppl 1):1203-9.

70. Boucher R, Demassieux S, Garcia R, Genest J. Tonin, angiotensin II system, a review. Circ Res 1977;41:26-9.

71. Okunishi H, Miyazaki M, Toda N. Evidence for a putatively new angiotensin II-generating enzyme in the vascular wall. J Hypertens 1984;2:277-84.

72. U rata H, Healy B, Stewart RW, Bumpus FM, Husain A. Angiotensin II-forming pathways in normal and failing human hearts. Circ Res 1990;66(4):883-90.

73. Roks A, Buikema H, Pinto YM, van Gilst WH. The reninangiotensin system and vascular function: the role of angiotensin II, angiotensin converting enzyme, and alternative conversion of angiotensin I. Heart Vessels 1997:suppl 12:119-24

74. Mosimann R, Imboden H, Felix D. The neuronal role of angiotensin II in thirst, sodium appetite, cognition and memory. Biol Rev 1996;71:545-59.

75. Campbell D. Circulating and tissue angiotensin systems. J Clin Invest 1987;79:1-6.

76. Dzau VJ. Circulation versus local renin-angiotensin system in cardiovascular homeostasis. Circulation 1988;77(suppl 1):14-13.

77. Unger T, Gohilke P, Paul M, Rettig R. Tissue reninangiotensin systems: fact or fiction? J Cardiovasc Pharmacol 1991;18(suppl 2):S20-5

78. Chiu AT, Herblin WF, McCall DE, et al. Identification of angiotensin II receptor subtypes. Biochem Biophys Res Commun 1989;165:196-203.

79. Whitebread S, Mele M, Kamber B, de Gasparo M. Preliminary biochemical characterization of two angiotensin II receptor subtypes. Biochem Biophys Res Commun 1989;163:284-91.

80. Wharton J, Morgan K, Rutherford AD, et al. Differential distribution of angiotensin $\mathrm{AT}_{2}$ receptors in the normal and failing human heart. J Pharmacol Exp Ther 1998;284:323-36.

81. Nozawa $\mathbf{Y}$, Haruno A, Oda N, et al. Angiotensin II receptor subtypes in bovine and human ventricular myocardium. J Pharmacol Exp Ther 1994;270:566-71.

82. Rogg H, de Gasparo M, Graedel E, et al. Angiotensin IIreceptor subtypes in the human atria and evidence for alterations in the patients with cardiac dysfunction. Eur Heart 1996;17:1112-20.

83. Sander GE, McKinnie JJ, Greenberg SS, Giles TD. Angiotensin-converting enzyme inhibitors and angiotensin II receptor antagonists in the treatment of heart failure caused by left ventricular systolic dysfunction. Prog Cardiovasc Dis 1999;41:265-300.
84. Bottari SP, Taylor V, King IN, Bogdal Y, Whitebread S, de Gasparo $\mathbf{M}$. Angiotensin II $\mathrm{AT}_{2}$ receptors do not interact with guanine nucleotide binding proteins. Eur J Pharmacol 1991;207:157-63.

85. Garrison JC, Johnson DE, Campanile CP. Evidence for the role of phosphorylase kinase, protein kinase $C$ and other $\mathrm{Ca} 2+$ sensitive protein kinases in the response of hepatocytes to angiotensin II and vasopression. J Biol Chem 1988;259:3283-92

86. Buisson B, Bottari SP, de Gasparo M, Gallo-Payet N, Payet MD. The angiotensin $A T_{2}$ receptor modulates $T$-type calcium current in non-differentiated NG $108-15$ cells. FEBS Lett 1992;309:161-4.

87. Chung $\mathbf{O}, \mathbf{C}$ sikos $\mathbf{T}$, Unger $\mathbf{T}$. Angiotensin II receptor pharmacology and $\mathrm{AT}_{1}$-receptor blockers. J Hum Hypertens 1999;13(suppl 1):S11-20.

88. Ohyama K, Yamano Y, Chaki SW, et al. Domains of G-protein coupling in angiotensin II receptor type I: studies by sitedirected mutagenesis. Biochem Biophys Res Commun 1992;189:677-83.

89. Spat A, Enyedi P, Hajnoczky G, et al. Generation and role of calcium signal in adrenal glomerulosa cells. Exp Physiol 1991;76:859-85.

90. Marrero MB, Schieffer B, Paxton WG. Direct stimulation of Jak/STAT pathway by the angiotensin II AT 1 receptor. Nature 1995;375:247-50.

91. Pan J, Fukuda K, Kodama J, et al. Role of angiotensin II in activation of the JAK/STAT pathway induced by acute pressure overload in the rat heart. Circ Res 1997;81:611-17.

92. Marrero MB, Schieffer B, Li B, Sun J, Harp JB, Ling BN. Role of Janus kinase/signal transducer and activator of transcription and mitogen-activated protein kinase cascades in angiotensin II and platelet-derived growth factor-induced vascular smooth muscle cell proliferation. J Biol Chem 1997;272:24684-90.

93. Bhat GJ, Thekkumkara TJ, Thomas W G, Conrad KM, Baker KM. Angiotensin II stimulates sis-inducing factor-like DNA binding activity. Evidence that the AT 1 receptor activates transcription factor-Stat91 and/or a related protein. J Biol Chem 1994;269:31443-9.

94. Sadoshima J-I, Izumo S. Signal transduction pathways of angiotensin II-induced c-fos gene expression in cardiac myocytes in vitro. Role of phospholipid-derived second messengers. Circ Res 1993;73:424-38.

95. Kawahara Y, Sunako M, Tsuda T, Fukuzaki H, Fukumoto Y, Takai $Y$. Angiotensin II induces expression of the c-fos gene through protein kinase $\mathrm{C}$ activation and calcium ion mobilization in cultured vascular smooth muscle cells. Biochem Biophys Res Commun 1988;150:52-9.

96. Naftilan A, Pratt RE, Eldridge CS, Dzau VJ. Angiotensin II induces c-fos expression in smooth muscle cells via transcriptional control. Hypertension 1989;13:706-11.

97. Taubman MB, Berk BC, Izumo S, Tsuda T, Alexander RW, Nadal-Ginard B. Angiotensin II induces C-fos mRNA in aortic smooth muscle. J Biol Chem 1989;264:526-30.

98. Gohlke P, Pees $\mathbf{C}$, Unger $\mathbf{T}$. AT 2 -receptor stimulation increases aortic cyclic GMP levels in SHRSP by a kinindependent pathway. Hypertension 1998;31:349-55.

99. Stoll M, Steckelings UM, Paul M, Bottari SP, Metzger $R$, Unger $\mathbf{T}$. The angiotensin $\mathrm{AT}_{2}$-receptor mediates inhibition of cell proliferation in coronary endothelial cells. J Clin Invest 1995;95:651-7.

100. Nakajima M, Hutchinson HG, Fujinaga $\mathbf{M}$, et al. The angiotensin II type $2\left(\mathrm{AT}_{2}\right)$ receptor antagonizes the growth effects of the $A T_{1}$ receptor: gain of function study using in vivo gene transfer. Proc N atl Acad Sci USA 1995;92:10663-7.

101. Meffert S, Stoll M, Steckelings MU, Bottari SP, Unger T. The angiotensin $A T_{2}$ receptor inhibits proliferation and promotes differentiation in $\mathrm{PC} 12 \mathrm{~W}$ cells. Mol Cell Endocrinol 1996;122:59-67.

102. Yamada T, Horiuchi M, Dzau VJ. Angiotensin II type 2 receptor mediates programmed cell death. Proc Natl Acad Sci USA 1996;93:156-60. 
103. Tanaka M, Ohnishi J, Ozawa Y, Sugimoto M, Usuki S, Naruse M. Characterization of angiotensin II receptor type 2 during differentiation and apoptosis of rat ovarian cultured granulosa cells. Biochem Biophys Res Commun 1995;207: 593-8.

104. Hajnoczky G, Varnai P, Hollo Z, et al. Thapsigargin-induced increase in cytoplasmic $\mathrm{Ca}^{2+}$ concentration and aldosterone production in rat adrenal glomerulosa cells: interaction with potassium and angiotensin-II. Endocrinology 1991;128: 2639-44.

105. Szalay KS, Beck $\mathbf{M}$, Toth $\mathbf{M}$, de $\mathbf{C}$ hatel $\mathbf{R}$. Interactions between ouabain, atrial natriuretic peptide, angiotensin-II and potassium: effects on rat zona glomerulosa aldosterone production. Life Sci 1998;62:1845-52.

106. Okubo S, Niimura F, Nishimura $\mathbf{H}$, et al. Angiotensinindependent mechanism for aldosterone synthesis during chronic extracellular fluid volume depletion. J Clin Invest 1997;99:855-60.

107. Ayers CR, Davis J0, Lieberman F, Carpenter CCJ, Berman $M$. The effects of chronic hepatic venous congestion on the metabolism of $d, l$-aldosterone and d-aldosterone. J Clin Invest 1962;41:884-95.

108. Tait JF, Bougas J, Little B, Tait SAS, Flood C. Splanchnic extraction and clearance of aldosterone in subjects with minimal and marked cardiac dysfunction. J Clin Endocrinol Metab 1965;25:219-28.

109. MacFadyen RJ, Lee AFC, Morton J, Pringle SD, Struthers AD. How often are angiotensin II and aldosterone concentrations raised during chronic ACE inhibitor treatment in cardiac failure? Heart 1999;82:57-61.

110. Struthers AD. Why does spironolactone improve mortality over and above an ACE inhibitor in chronic heart failure? Br J Clin Pharmacol 1999;47:479-82.

111. Biollaz J, Brunner HR, Gavras I, et al. Antihypertensive therapy with MK 421: angiotensin II-renin relationships to evaluate efficacy of converting enzyme blockade. J Cardiovasc Pharmacol 1982;4:966-72.

112. Slight SH, Joesph J, Ganjam VK, Weber KT. Extra-adrenal mineralocorticoids and cardiovascular tissue. J Mol Cell Cardiol 1999:31:1175-84

113. Takeda Y, Miyamori I, Yoneda T, et al. Production of aldosterone in isolated rat blood vessels. Hypertension 1995;25:170-3.

114. Silvestre J-S, Robert V, Heymes C, et al. Myocardial production of aldosterone and corticosterone in the rat: physiological regulation. J Biol Chem 1998;273:4883-91.

115. Swedberg K, Eneroth P, Kjekshus J, et al. Hormones regulating cardiovascular function in patients with severe congestive heart failure and their relation to mortality. Circulation 1990;82:1730-6.

116. Barr C S, Lang C C, Hanson J, Arnott M, Kennedy N Struthers AD. Effects of adding spironolactone to an ACE inhibitor in chronic congestive heart failure secondary to coronary artery disease. Am J Cardiol 1995;76:1259-65.

117. Wang W, McClaim JM, Zucker IH. Aldosterone reduces baroreceptor discharge in the dog. Hypertension 1992 19:270-7.

118. Wang W. Chronic administration of aldosterone depresses baroreceptor reflex in the dog. Hypertension 1994;24:571-5

119. Yee KM, Struthers AD. Aldosterone blunts the baroreflex response in man. Clin Sci 1998;95:687-92.

120. Myers RW, Pearlman AS, Hayman RM, et al. Beneficial effects of vagal stimulation and bradycardia during experimental acute myocardial ischaemia. Circulation 1974;49:943-7.

121. Zuanetti G, Ferrari GM, Proiri SG, Schwartz PJ. Protective effect of vagal stimulation on reperfusion arrhythmias in cats. Circ Res 1987:61:429-35.

122. Brilla C G, Matsubara LS, Weber KT. Anti-aldosterone treatment and the prevention of myocardial fibrosis in primary and secondary hyperaldosteronism. J Mol Cell Cardiol 1993;25:563-75.

123. MacFadyen RJ, Barr C S, Struthers AD. Aldosterone blockade reduces vascular collagen turnover, improves heart rate variability and reduces early morning rise in heart rate in heart failure patients. Cardiovasc Res 1997;35:30-4.

124. Weber KT, Brilla CG. Pathological hypertrophy and cardiac interstitium: fibrosis and renin-angiotensin-aldosterone system. Circulation 1991;83:1849-65.

125. Duprez DA, De Buyzere ML, Rietzschel ER, et al. Inverse relationship between aldosterone and large artery compliance in chronically treated heart failure patients. Eur Heart J 1998:19:1371-6.

126. Rocha R, Chander PN, Khanna K, Zuckerman A, Stier CT Jr. Mineralocorticoid blockade reduces vascular injury in strokeprone hypertensive rats. Hypertension 1998;31:451-8.

127. Robert V, Heymes C, Silvestre JS, Sabri A, Swynghedauw B, Delcayre C. Angiotensin $\mathrm{AT}_{1}$ receptor subtype as a cardiac target of aldosterone: role in aldosterone-salt-induced fibrosis. Hypertension 1999;33:981-6. 